\title{
Ibn Khaldun's Theory of 'Asabiyyah and Its Impact on the Current Muslim Community
}

\author{
Nurul Fadhilah Binti Ismail, Adibah Binti Abdul Rahim \\ International Islamic University Malaysia (IIUM), Gombak, Malaysia
}

\begin{abstract}
This paper seeks to study the theory of 'asabiyyah by Ibn Khaldun, a well-known North African historiographer from 14th century. It examines Ibn Khaldun's original thoughts on 'asabiyyah and how he did retool it for the beneficial purposes. At the same time, the paper tries to compare the term of 'asabiyyah as proposed by Ibn Khaldun with the interpretation made by the West in the current world. This study also will give some inputs on the implementation of Ibn Khaldun's theory of 'asabiyyah, and it will expose how the theory could benefit the Muslim civilization to soar as a great nation. The descriptive method has been used in this study to present the right information about Ibn Khaldun and his theory. It is hoped that this study could enhance our understanding on the term of 'asabiyyah in its positive connotation, as the term has been recognized negatively among people today.
\end{abstract}

Keywords: Ibn Khaldun, al Muqaddimah, 'asabiyyah, Muslim civilization, Muslim community (ummah)

\section{Introduction}

Ibn KhaldËn is one of the greatest thinkers in the world whom the documentary of his life is easy to access and find, unlike his other contemporaries whom not much of their information are obtainable. He was regarded as one of the founding father of sociology, historiography, and economics. His intelligence, brilliance, and curiosity towards knowledge and education had shaped him into an intellectual person who had also an interest towards political and social issues (The Famous People, 2016).

Ibn KhaldËn turned out to be a great Muslim scholar who had attained recognition in numerous parts of the world, a perfect example of the cohesion of being a Muslim and scientist (Al-Halabi, 2013). He contributed his ideas in many fields and not merely confined to the religious framework. He can be considered as a determined researcher on the basis of science and knowledge. Being a well-known expert in history, Ibn Khaldun questioned the facts exposed by scholars who are lack of reasoning; the content of their work consist of historical errors, and they used exaggerate approaches (Ibrahim Lubis, 2012).

Ibn Khaldun has a vast knowledge and his contributions become the subject of conversation among other writers and scholars. In the field of sociology, James Conyers proposed that "Ibn KhaldËn should be given an appropriate place in the field in which he meant as the founder" (Al-Halabi, 2013, p. 4).

Nurul Fadhilah binti Ismail, M.A. in Islamic Revealed Knowledge and Heritage, Kulliyyah of Islamic Revealed Knowledge and Human Sciences, International Islamic University Malaysia (IIUM).

Adibah binti Abdul Rahim, Ph.D. in Islamic Revealed Knowledge and Heritage; Associate Professor in the Department of Usul al Din and Comparative Religion, Kulliyyah of Islamic Revealed Knowledge and Human Sciences, International Islamic University Malaysia (IIUM). 
In the field of economic, J. D. C Boulakia had attributed the origin of the economic growth to Ibn KhaldËn (Al-Halabi, 2013). In the field of history, Harry Elmer Barnes stated that "Ibn KhaldËn's importance as a philosopher of history lays in the fact that he rationalized the subject and reflected on its method and purposes" (Al-Halabi, 2013, p. 4). That is the reason, according to Hyden V. White, "there is a dispute between historians and sociologist for the honor of claiming him as their own" (Al-Halabi, 2013, p. 4).

Despite his contributions to the several knowledges, his theory of "al̂́Ebiyyah has given another impact to the Muslim world during his time. His theory of 'aÎÉbiyyah differs from others whom interpret it as a negative connotation up until today. Ibn KhaldËn used the term 'aĺÉbiyyah as to describe the bond of unity among human in a group to form community (Ibrahim, 2015). It is not meant solely based on blood ties or common interest, but also people from the other group. This concept of "al̂Ébiyyah is the dominant theme in Muqaddimah, an introduction in his book "Kitab al-'Ibar". Muqaddimah is a detailed study of human society that provides a summarized version of his ideas about numerous branches of knowledge during his time (Al-Halabi, 2013). His work is employed to explore the inner logic of the rise and fall of a civilization, and the origin and evolution of human society (Musthafa, 2015). Ibn KhaldËn's theory of 'al̂́biyyah can be seen to have many definitions among contemporary scholars in which not all can be regarded as the actual meaning of his theory.

This paper is using descriptive, analytical, and indirectly comparative method in studying Ibn KhaldËn's thought on the theory of 'ấÉbiyyah. Firstly, this paper will look into the life of Ibn KhaldËn examining his name and family lineage, his early childhood, his dates of birth and death, his education, his profession, and his major works. Secondly, the study has discussed on Ibn KhaldËn's theory of 'ấÉbiyyah which consists of its definition and the reason he advocates the theory. Thirdly, the definition of the theory of 'al̂́biyyah and its relevance to the contemporary Muslim community will also be discussed; at the same time, this paper highlights how Ibn KhaldËn's theory of 'ấÉbiyyah is different from others' interpretations.. Finally, the paper focuses on the application of Ibn KhaldËn's theory of 'ấÉbiyyah in contemporary Muslim community.

\section{Intellectual Background of Ibn KhaldËn}

The contribution of Ibn KhaldËn in several fields of knowledge is recognized by both Muslim and non-Muslim scholars especially his vast knowledge in the field of History and Sociology in Muslim history. It is of great significance to examine and identify his intellectual background as well as his works to further understand his thoughts on 'ấÉbiyyah.

Ibn KhaldËn's full name is Wali al-Din Abd al-Rahman ibn Muhammad ibn Muhammad ibn Muhammad ibn al-Hassan ibn Jabir ibn Muhammad ibn Ibrahim ibn Abd al-Rahman ibn KhaldËn. Some authors stated that Ibn Khaldun belonged to an Andalusian family which then migrated to Tunisia from Andalusia in the middle of the seventh century. Ibn KhaldËn was born and raised in Tunisia, on 1st Ramadhan 732 A.H./27th May 1332 AD (Musthafa, 2015). However, there are contradictory statements about the date of his death. Some writers mentioned that he died while he was in the office on 25th Ramadhan 808 A.H./17th March 1406 AD (Hozien, 2016). There are writers who mentioned that his death date was on 26th Ramadhan 808 A.H./16th March 1406 AD (Abdullah Enan, 1941), while others said that he died on 19th March 1406 AD (The Famous People, 2016). But all those writers who wrote about him mentioned the same year undoubtedly and his buried place was in the Sufi Cemetery outside Bab an-Nasr, Cairo at the age of 74 years old (Abdullah Enan, 1941). 
Ibn KhaldËn's education was not merely related to the religious field, but also in the academic field as well. He was brought up in a prominent and learned family. His first teacher was his father himself. He read and learnt the Qur'Én by heart and later on received the title "al-HÉfiz" after he had memorized it at a very young age. He then learnt grammar, HadÊth, jurisprudence, Arabic poetry, mathematics, logic, and philosophy. In terms of profession, Ibn KhaldËn spent most of his lifetime being a judge. Other than that, he had been working as a statesman, a diplomat in several places including Morocco, Granada, and Tunisia. However, every place that he was assigned to, jealousy strikes among his colleagues that made him decide to leave and quit. He then decided to travel to Cairo before he went to a famous place in the Mashriq. He had been assigned as the grand judge in Cairo in which he spent 15 years of his life in that country.

Throughout his life, he encountered a lot of knowledge and wrote a lot of works. The main work of Ibn

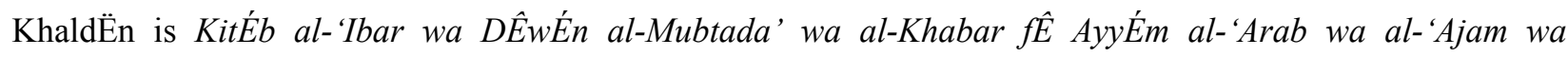
al-Barbar wa Man 'ấarahum min Dawl al-SulÏÉn al-Akbar or known as KitÉb al-'Ibar, a seven volume history book (New World Encyclopedia, 2016). However, the most significance work of his was the Muqaddimah, an introduction in KitÉb al-'Ibar, and some would consider it as not part of the book (New World Encyclopedia, 2016). Though many would say that the Muqaddimah or also known as Prolegomena that made him best known and recognized as it received a much wider response than the book itself not only in the Muslim world, but also in the Western world, one should not forget that the book was his effort, and thus, it should not be neglected. Nevertheless, the Muqaddimah was his masterpiece where it represented an attractive way of viewing the origin, development, progress, and fall of a civilization generally, and medieval Muslim civilization particularly (Musthafa, 2015).

In his KitÉb al-'Ibar, he used several methods to explain his thoughts, including empirical, observation, and comparative and historical methodologies. It can also be seen as the details of sociology. KitÉb al-'Ibar consisted seven volumes including the Muqaddimah. The first and second chapters of the book discussed about human civilization in general, and Bedouin society, respectively. The third chapter talked on government ranks, royal authority, and the caliphate. Information on countries, cities, and all other forms of sedentary civilization were discussed on the fourth chapter of the book. As for the fifth and the sixth chapters, he discussed on the various means of livelihood and knowledge, respectively (Khaldun \& Rahman, 2012).

Apart from KitÉb al-'Ibar with vast knowledge in hand, he did not only focus on sociology alone. Ibn KhaldËn has poured some of his thoughts on other field of knowledge and turns them into his minor works. At the age of 1 years, under the supervision of his teacher in Tunis, he wrote his first book on a commentary on the

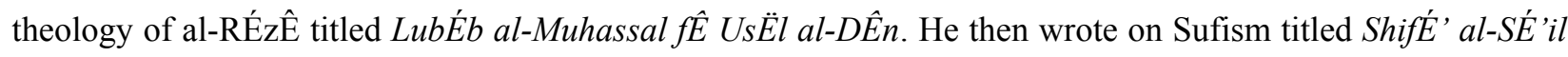
li TahdhÊb al-MasÉil, and had also a work on logic titled 'Allaqa li al-SulÏÉn (New World Encyclopedia, 2016). Nevertheless, his Muqaddimah is so influential and is still benefitting many minds and becoming the source of reference to those who are doing a research within that framework. Although his works involved various types of field, there was no information or details on his successors.

\section{'ẤÉbiyyah From an Islamic Perspective}

Before we look into Ibn KhaldËn's theory of 'aÎ́Ebiyyah and its interpretation based on other scholars, we need to identify the term 'aĺÉbiyyah from Islamic perspective as to make it more transparent and in line with divine sources. The term 'aÎÉbiyyah has been mentioned in both the Qur'Én and the HadÊth. An example from the Qur'Én, it is described to be rooted from the word ' $u \hat{I} b a h$, as to describe the great relationship and bond of a 
sect (Ab Halim, 2014). It has been mentioned four times in different places, such as in sërah an-NËr verse 11:

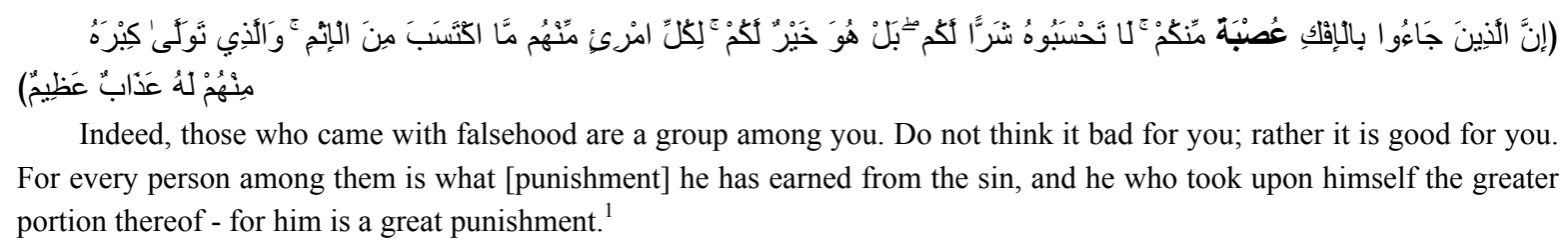

Indeed, those who came with falsehood are a group among you. Do not think it bad for you; rather it is good for you. For every person among them is what [punishment] he has earned from the sin, and he who took upon himself the greater portion thereof - for him is a great punishment. ${ }^{1}$

Here, the term is used to describe a group of slanderers who had created a lie and rumour about 'Ó'ishah, wife of the Prophet (peace be upon him). It is to be said that the group consists of more than two people, thus, the verse represents the involvement of many people, establishing a strong group (Ab Halim, 2014). Differ from the book of Allah, the prophetic tradition clearly stated the condemnation of 'ấÉbiyyah in Islam, as Prophet Muhammad (peace be upon him) said:

$$
\text { ليس منا من دعا إلى عصبية وليس منا من قاتل على عصبية وليس منا من مات على عصبية }
$$

He is not of us who proclaims the cause of tribal partisanship ('â̂́Ébiyyah); and he is not of us who fights in the cause of tribal partisanship ('ấÉbiyyah); and he is not of us who dies in the cause of tribal partisanship ('â̂Ébiyyah).

Then Prophet Muhammad (peace is upon him) was asked by one of his ÎÍÉbah the meaning of tribal partisanship ('ấÉbiyyah), he then replied:

$$
\text { أن تعين قومك على الظلم }
$$

(It means) you are helping your own people in an unjust cause

Hence, this type of 'al̂́biyyah as described by the Prophet (peace is upon him) can be understood as being unfair and biased or providing support merely to their own group with prejudice or for unjust motives and actions. It is permissible to love one's own people. In fact, it is encouraged in Islam to love and care for our brothers. But if a Muslim is being unfair or assist his member in doing wrong to other people from different groups, this is what condemned by Islam, as Muslims are discouraged to unite merely based on race, skin color, or any physical features and qualities (Ab Halim, 2014).

\section{Ibn KhaldËn's Theory of 'ÂIÉbiyyah}

As far as the term 'ấÉbiyyah is concerned, it relates to the social interaction more than the individual. Ibn KhaldËn looks at the term 'ấÉbiyyah in positive connotation. When others, particularly the West, put their attention on the individuality, Ibn KhaldËn focuses on the group or the society. To him, it was the history's essential point and influential factor. Neglecting individuality did not stop him from exploring the nature and characteristics of human beings. To him, man by nature, is a social animal and at the same time man is also an animal being who has desire, and on top of that, they have been given the intellectual for reasoning and supported with revelation by God (Sümer, 2012). Hence, for man to implement all what they have and what have been given to them, society involvement is needed and necessary, so that they are able to spread and share their intellectual ideas and thoughts. In other word, since individual man is lack of virtue and quality and has low level of intelligence, society could change them and they could hold together if only they act as one. This is what he meant by 'ấÉbiyyah (Sümer, 2012). According to Ibn KhaldËn, 'ấÉbiyyah, as he mentioned in the Muqaddimah, it is "the group feeling with which a human being feels most closely connected to his relatives

\footnotetext{
${ }^{1}$ See https://quran.com/24:11.
} 
primarily, the people whom he shares a common descent". But as a feeling and a state of mind, it can also be shared by people who have no relation with each other, only close connection as members and followers of a group (Abdullah, 2014).

Ibn Khaldun manifests the term 'ấÉbiyyah in a complex manner. He points out that to ensure cooperation to exist on a larger scale of human beings, 'aÎÉbiyyah is a must, the term that he borrowed from traditional and standard usage to which he turned it into new positive interpretation. It is when others are using it for negative connotation; Ibn KhaldËn applies it with a purpose, which is to unite people politically even though they are not related by blood ties (Sümer, 2012). Hence, his theory concerns more on society or group unity. It can also be described as a natural feeling of human beings in which it acts as a protecting tool when their group members are treated unfairly (Ab Halim, 2014).

Although the term 'al̂́biyyah has its negative connotation which leads to the condemnation in Islam as mentioned, it can also be applied for positive purposes. However, as one would like to employ it in positive aspect as possible, one should not compare it with the concept of brotherhood in Islam. 'ẤÉbiyyah is more concerned on social groups; unlike the concept of brotherhood, it is based on races, justice, faith, languages, and all kind of physical differences. Thus, both have their own interpretations and purposes (Ab Halim, 2014).

Additionally, his theory of 'ấÉbiyyah started after he notices that there are two types of culture: the Bedouin (rural society) and the sedentary (urban society). They are not related and are opposite of each other (Islamica, 1996). In this sense, 'ấÉbiyyah here relates to the Bedouin society due to their primitive life that they possessed (Abdullah, 2014). This also force them to stand together to protect their family and their members from danger. Ibn KhaldËn explained further that due to fighting for their basic needs, it then emerges the spirit of the group feeling or 'ấÉbiyyah among them (Abdullah, 2014). The Bedouins can be seen to be more brave and daring compared to those in city, probably due to living in the desert that requires them to behave as such (Islamica, 1996). Meanwhile, civilized people resort to governmental laws and regulations and hence, there is no issue of struggle to them. But, conflict between two tribes will lead to several wars (Islamica, 1996). In fact, the tribe with more powerful and strongest unity shall rule another tribe. From here, the concept of kingship develops. This kingship or also known as royal authority is regarded as a requirement tool, so that he (the king) able to avoid tribes fighting and to give social cohesion. Besides that, religion too provides 'aÎ́biyyah as it abolishes the jealousy among them, which then creates the ideal civilization (Islamica, 1996).

Above all, that was how Ibn KhaldËn uses the term 'ấÉbiyyah as to describe the bond that exists at any level of civilization, from nomadic society, to states, though it is much stronger in the nomadic phase (Ibrahim, 2015). He also clarified that one of the critical element that influences the rise and fall of a community is 'ấÉbiyyah (Islamica, 1996). When 'ấÉbiyyah is strong, the civilization will rise and when 'ấÉbiyyah is weak, the civilization will fall, and then, a new tribe with a stronger and powerful 'ấÉbiyyah rises and take charge. Hence, civilization will grow, be mature, decay and then death invites. This is the cyclic stage of civilization (Islamica, 1996).

\section{The Application of 'AÎ́Ébiyyah to the Contemporary Muslim Community}

There are several interpretations and translations with regards to the term 'asabiyyah. One would interpret it as group consciousness, corporate spirit, feeling of solidarity, social solidarity, and so on. Others would generally understand it as 
man's supporting his people, to whom he belongs, whether they are right or wrong, oppressing or oppressed. These people fit in the same sect can be due to kin, ethnicity, color, birth place, citizenship, school of thought, or a group of people with a common interest. (Ab Halim, 2014, p. 34)

Based on the Arab-English Dictionary, the term 'aÎÉbiyyah is explained to be the characteristic of a man who possesses 'ấÉbiyyah, in which it helps his group members against hostility, or it can also be said as a person being fanatic towards its own group, up to the extent that he acts vigorously to support and defend them (Ab Halim, 2014). Nevertheless, there are writers who came to the conclusion to use the term in Arabic as it is, as this will maintain the real meaning of 'ấÉbiyyah used by Ibn KhaldËn (Ab Halim, 2014).

Today, no Muslim communities practice 'â̂́Ébiyyah as prescribed by Ibn KhaldËn. The only 'â̂́Ebiyyah that we can find is the standard meaning defined by the West, that is, a group with larger followers will condemn another group that has only few members for the sake of helping and defending his own group member though he is at fault. Up to the extent, they will fight amongst them just to show who is more powerful. On top of that, the groups will only follow their own group, either their members are in the right or wrong possession.

Focusing the scope to the Malay Muslim community, most of them have improved themselves to have a better standard living than previous years undoubtedly. However, there is an inner conflict within the Malay Muslim parties themselves. For instance, Malaysia has several political parties with different ideologies, thoughts, and understanding, such as United Malay Nation Organization or known as UMNO and Pan-Malaysian Islamic Party or known as PAS. Instead of being together in upholding the rights of Islam for a country, the two parties were arguing and accusing each other (Halim, Mohd Nor, Ibrahim, \& Abdul Hamid, 2012). It is to be said that in 1987, the two parties had an open attack and condemning each other of being "infidels", in which in Islamic teaching it is a serious matter to accuse one's infidelity (Halim et al., 2012). In addition, the community is also having social problems, such as drug addiction, broken families, back-stabbing, and so on. All these problems are indeed crucial and critical, and in need of more educated people to educate the society that they should be the one who change for the better to ensure the country is safe and not in the state of regression (Halim et al., 2012). Therefore, the theory of 'asabiyyah as proposed by Ibn Khaldun could be the means to unite Muslims and overcome the challenges facing them today.

In order to reflect on Ibn KhaldËn's theory of 'aÎ́Ebiyyah in developing a society, two important elements have been advocated and need to be achieved to ensure the strength of Muslim community. Firstly, they need to understand the true concept of 'ấÉbiyyah, so that they are able to support each other although they have no blood relations. Secondly, they need to empower the belief in the concept of Tawhid as the foundation of life. The concept of Tawhid implies the unity of people on the basis of religious belief regardless of different races, color skins or socio-political background. the When the concept of 'asabiyyah is understood and manifested in a positive manner and the ideals concept of tawhid are implemented, the Muslim community is able to unite and this unity is important in order to strengthen the ummah to overcome the problems posed by the external challenges particularly the West.

It is important to note that the theory of 'asabiyyah as proposed by Ibn Khaldun was not meant to deviate oneself from the religion. His theory is crucial for Muslims in order to rise up and stand as one strong nation. As much as 'asabiyyah is considered to be dangerous among some people, there are few positive aspects that can be derived from the term. Unquestionably, Ibn KhaldËn continues to be one of the most significant Muslim scholars whom contribution can be the source of reference and still relevant until today. 


\section{Conclusion}

Although the term 'asabiyyah has been frequently used in a negative connotation, Ibn Khaldun tried to identify the positive aspects of 'asabiyyah by implementing it for positive purposes. For him, 'asabiyyah is a natural feeling of human beings as a protection of their group members. Ibn Khaldun observed 'asabiyyah as the bond of unity, and the cause of mutual recognition and assistance. In addition, he regarded 'asabiyyah as the source of the internal strength of Muslims. The sentiment of belonging to a certain group, according to Ibn Khaldun, was a natural phenomenon. In Islamic perspective, it is acceptable as long as it is no claim of superiority over nations and no loyalty of nation over religion. In Ibn Khaldun's view, 'asabiyyah is only a single aspect of Islamic unity which encourages people to unite. When people are united unifying force of religion, they could become strong and enabled to defeat any threat. Ibn Khaldun stressed that the sentiment of asabiyyah will eventually contribute to not only the social unity but also the political power. He discouraged people to be individualistic because individualism was one of the main reasons for the downfall of the society. When people have emotional attachment to a group, they will not become selfish but act in collective interest. In this sense, people should not only focus on their own personal benefits but to consider other fellow beings at the same time. In short, the term 'asabiyyah in Ibn Khaldun's views can be considered as the dynamic power for social cohesion, and its absence would lead to a social disintegration. Most importantly, upholding the social cohesion in Islam is regarded as a religious obligation.

\section{References}

Ab Halim, A. (2014). Ibn Khaldun's theory of 'Asabiyyah and the concept of Muslim Ummah. Retrieved December 12, 2016, from http://repository.um.edu.my/95233/1/Article\%2004\%20Asabiyyah\%20Ibn\%20Khald\%3Fn\%20and\%20Muslim\%20Ummah.pdf

Abdullah Enan, M. (1941). Ibn Khaldun: His life and work. (S. M. Ashraf, Trans.). Lahore, India: Kashmiri Bazar. Retrieved December 13, 2016, from http://apnaorg.com/books/english/ibn-e-khuldun/ibn-e-khuldun.pdf

Abdullah, M. I. (2014). The theory of Ibn Khaldun's 'Asabiyyah and the consequence in the Islamic World. International Islamic University Malaysia. Retrieved December 12, 2016, from http://jrismail.blogspot.my/2014/12/international-islamic-university.html

Al-Halabi, K. M. A. (2013). Ibn Khaldun's theory of knowledge and its educational implications. International Islamic University $\begin{array}{lllll}\text { Malaysia. } & \text { Retrieved } & \text { December } & 13, & \text { 2016, }\end{array}$ http://www.lib.iium.edu.my/mom2/cm/content/view/view.jsp?key=b4n7WiFqqprJQlrnRg110GZDFNtPF2AI20151022080814378

Basma, A. S. D. (2015). The ideal education in Ibn Khaldun's Muqaddimah. Jordan: Procedia-Social and Behavioral Sciences. Retrieved December $\quad 14, \quad 2016, \quad$ from http://ac.els-cdn.com/S1877042815035156/1-s2.0-S1877042815035156-main.pdf?_tid=a9f91a20-c218-11e6-aa54-00000aac b362\&acdnat=1481732367_167be48588eb4947d76796c2643e571e

Halim, A. A., Mohd Nor, M. R., Ibrahim, A. Z. B., \&Abdul Hamid, F. A. F. (2012). Ibn Khaldun's theory of 'Asabiyyah and its application in modern Muslim society. Middle-East Journal of Scientific Research, 11(9), 1232-1237. Retrieved December 17, 2016, from https://idosi.org/mejsr/mejsr11(9)12/11.pdf

Hozien, M. (2016) IBN KHALDUN: His life and work. Retrieved December 12, 2016, from http://www.muslimphilosophy.com/ik/klf.htm

Ibrahim, J. M. (2015). Why Ibn Khaldun is called one of the greatest thinkers of the Muslim world. Retrieved December 14, 2016, from http://mvslim.com/ibn-khaldun-one-of-the-greatest-thinkers-of-the-muslim-world/

Islamica, P. (1996). Ibn Khaldun: The strengthening and weakening of Asabiya. Retrieved December 13, 2016, from http://www.metafuture.org/library1/Macrohistory/ibn_khaldun_periodica_islamica_1996.pdf

Khaldun, M., \& Rahman, A. A. (2012). The Muqaddimah. (F. Rosenthal, Trans.). Retrieved December 16, 2016, from https://asadullahali.files.wordpress.com/2012/10/ibn_khaldun-al_muqaddimah.pdf

Musthafa, N. (2015). Origin and evolution of human society in Ibn Khaldun's philosophy of human development. India: Madeenathunoor College of Islamic Science. Retrieved December 14, 2016, from http://www.islamicpluralism.org/2469/origin-and-evolution-of-human-society-in-ibn 
Ibrahim Lubis. (2012). Biography of Ibn Khaldun-The foundation stone of the social sciences and political Islam. Retrieved December 14, 2016, from http://www.ib-article.com/2012/09/biography-of-ibn-khaldun-foundation.html

New World Encyclopedia. (2016). Ibn Khaldun. Retrieved December 12, 2016, from http://www.newworldencyclopedia.org/entry/Ibn_Khaldun\#Works

SÜMER, B. (2012). Ibn Khaldun's asabiyya for social cohesion. Turkey: Electronic Journal of Social Sciences. Retrieved December 12, 2016, from http://dergipark.ulakbim.gov.tr/esosder/article/viewFile/5000068522/5000063584

The Famous People. (2016). Ibn Khaldun: Biography. Retrieved December 12, 2016, from http://www.thefamouspeople.com/profiles/ibn-khaldun-6026.php 